\title{
Analysis of the Effects of Traffic Volume on the Pavement Condition in the Educational Zone of Merauke Regency
}

\author{
Dewi Sriastuti Nababan ${ }^{1}$, Herbin Florensius Betaubun ${ }^{2}$, Theresia Widi Asih Cahyanti ${ }^{3}$, Budi Doloksaribu ${ }^{4}$, Jeni Paresa $^{5}$ \\ Civil Engineering Department \\ Universitas Musamus \\ Merauke, Indonesia \\ ${ }^{1}$ nababan@unmus.ac.id, ${ }^{2}$ herbin@unmus.ac.id, ${ }^{3}$ cahyanti@unmus.ac.id, ${ }^{4}$ budi@unmus.ac.id, ${ }^{5}$ jeny@ $@$ unmus.ac.id
}

\begin{abstract}
Among types of land use vital for the development of Merauke Regency is the land use intended to provide its population with education. Land use for educational purposes (the educational zone) in Merauke Regency, such as the one in Pendidikan Road, Kamizaun Road, and Ternate Road, constitutes important access to schools and universities in the region. As a result, there is a fairly high volume of vehicles every day due to public activities to meet their educational needs. As a result of an increasing number of vehicle movements, there is an increase in the traffic volume, which includes motorcycles, light vehicles, and heavy vehicles in particular roads. Road damage results from several factors, one of which is the traffic volume [1]. In the event of damage to the road taken, the word "easy" will certainly be interpreted otherwise. This is descriptive quantitative research. This research describes the actual conditions of the research object using numbers. Based on the scores for the road condition index and traffic classes, it is revealed that the priority scores for Jl. Pendidikan, Jl. Kamizaun, and Jl. Ternate are 4 3, and 5, respectively. Based on those results, it is necessary to include Jl.Pendidikan and Jl.Ternate in the periodic maintenance program while Jl.Kamizaun needs to be included in the improvement program.Based on the whole data analysis undertaken, a model for the relationshipid179 between the traffic volume and the score for the pavement condition index was then examined. The analysis of the relationship model was undertaken using the application Microsoft Excel. The variables used in the analysis were the score for the pavement condition index as the dependent variable and the traffic volume as the independent variable. Results of the analysis undertaken using regression generated a multiple $R$ value of 0.4124 , which means that the traffic volume does not exercise a significant effect on the score for the pavement condition index, the $R$ square by 0.1701 means that the model's goodness of fit is not really good.
\end{abstract}

Keywords-traffic volume; road class; educational zone; pavement conditions

\section{INTRODUCTION}

Transportation always plays a vital role in the development of a region at national to regional level, especially in developing countries with population growth that continues to increase every year. This leads to an increasing demand for transportation services, thus it is definitely true that transportation plays a significant role in a developing region.
An increase in population growth in a region is always followed by an increase in the number of vehicles. The increasing number of vehicles will affect the rate of vehicle movements in the region. Basically, the movement of vehicle depends on their respective destination/ the movement of the subject making such a movement.

Merauke Regency is a developing region. This is evident from an increase in its population for the last five year, with an annual increase of $1.85 \%$ [2]. In the event of increasing population, the demand for a means of transportation will increase as well. Such a demand can be seen from the increasing number of vehicles. Based on data from SAMSAT, it is revealed that in 2017, the number of vehicles increases by $9.74 \%$ every year. This results in increasing vehicle movements in particular land use. The impact can be seen in the level of violation of speed limiting signs at the points surveyed in Merauke District is very high, especially the speed of vehicles 20-25 km / hour. [3]

One of the factors that affect the rate of movements of a city is land use development. Land use also indirectly influences side barriers in certain road conditions, activities can grow which can cause side barriers that greatly affect the characteristics of the road itself.[4] To meet his/ he needs, one will move from the first land use to the other land use, thereby resulting in the so-called trip generation and attraction, thus it can be concluded that traffic may be affected by land use and vice versa [5]. This suggests a strong relationship between land use and transportation.

Among types of land use vital for the development of Merauke Regency is the land use intended to provide its population with education. Land use for educational purposes inMerauke Regency, such as the one inJl. Pendidikan, Jl. Kamizaun, andJl. Ternate, constitutes important access to schools and universities in the region. As a result, there is a fairly high volume of vehicles every day due to public activities to meet their educational needs.

As a result of an increasing number of vehicle movements, there is an increase in the traffic volume, which includes motorcycles, light vehicles, and heavy vehicles in particular roads. Pavement damage results from several factors, one of which is the traffic volume [1]. Such an increase in the traffic 
volume will cause problems in the event of damage to the road taken.

Accessibility is a measure to determine the extent to which land use locations is deemed comfortable or convenient to interact one another, and the extent to which the access to those locations is deemed easy or not by a means of transportation. In the event of damage to the road taken, the word "easy" will be interpreted the opposite. This gets worse in the absence of routine road maintenance/ repairs that are not carried out in a timely manner due to certain constraints.

\section{METHOD}

\section{A. Research Type}

This is descriptive quantitative research. This research describesthe actual conditions of the research object using numbers. It aims to describe such conditions just the way they are.

\section{B. Research Site}

Surveys to collect data were undertaken in Jl. Pendidikan, J1. Kamizaun, and J1.Ternate in Merauke Regency. These roadslead to land use which fits the educational zone.

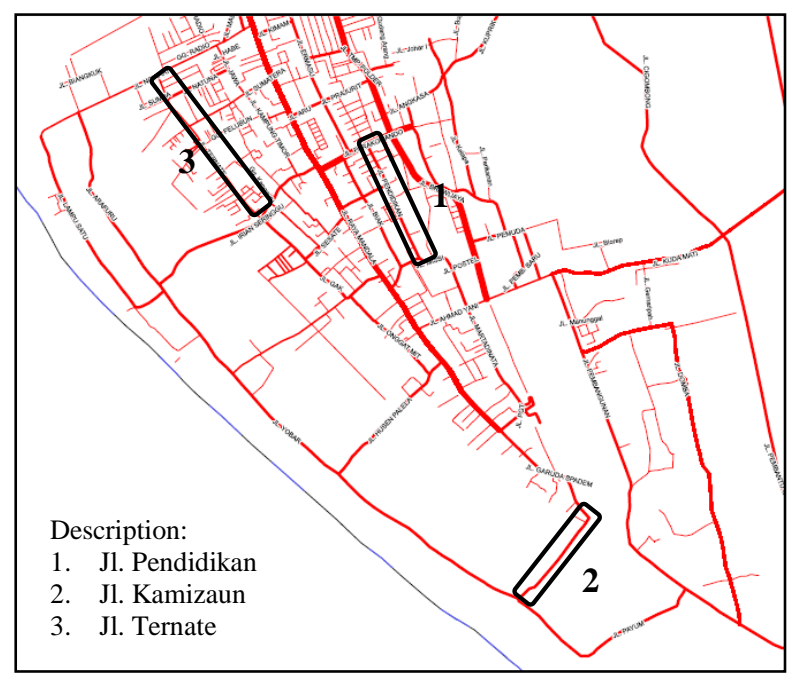

Fig. 1. Research Site

\section{Research Setting}

Measurement of the traffic volume was undertaken during peak hours for 7 days, starting from 06:00 - 18:00 Eastern Indonesia Time.Peak hours are used among others as the basis for geometric designing to determine the width of a lane, an intersection, and so on.

\section{Data Collection}

These surveys aim to determine the types and dimensions of road damage, road dimensions, and the traffic volume of vehicles moving along the roads surveyed. The data measured include: (1) road dimensions; (2) the traffic volume for motorcycles, light vehicles, and heavy vehicles; (3) pavement damage types; and (4) pavement damage dimensions.

The surveys were undertaken by a total of 3 surveyors, each conducted a survey in one of the three roads.
Measurement of road dimensions was performed while measuring the traffic volume. Measurement of road damage was undertaken by a total of 3 surveyors, each conducted a survey in one of the three roads.

\section{E. Data Analysis}

Volume was calculated by multiplying the number of vehicles by the Passenger Car Equivalent (PCE) based on the vehicle type classification. Road condition scores can be calculated using Procedures for City Road Maintenance Program Development 1990 [6] then analyzing traffic vehicle and pavement damage by regression method [7].

\section{RESULTS AND DISCUSSION}

\section{A. Traffic Volume and Average Daily Traffic}

Traffic volume refers to the number of vehicles moving along a particular road under a particular unit of time. The traffic volume was calculated by multiplying the number of vehicles moving along the road by the Passenger Car Equivalent (PCE)based on the type of vehicle[5].

TABLE I. PASSENGER CAR EQUIVALENTS

\begin{tabular}{|c|c|}
\hline Type of Vehicle & PCE \\
\hline Light Vehicle $(L V)^{3}$ & 1 \\
\hline Heavy Vehicle $(H V)^{3}$ & 1.3 \\
\hline Motorcycle $(M C)^{3}$ & 0.5 \\
\hline
\end{tabular}

The following are data on the traffic volume during the busiest day based on results of field measurement.



Fig. 2. Volume Data on the Busiest Day forJl. Kamizaun

Based on the traffic volume data in "Figure 2", the average daily traffic can be calculated, which is by 5101 passenger car unit/ day. 


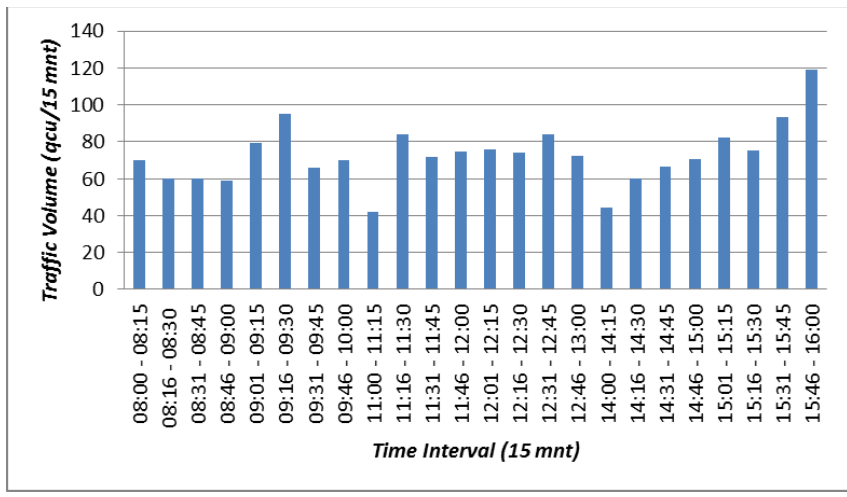

Fig. 3. Volume Data on the Busiest Day for Jl. Ternate

Based on the traffic volume data in "Figure 3", the average daily traffic can be calculated, which is by 3695passenger car unit/ day.

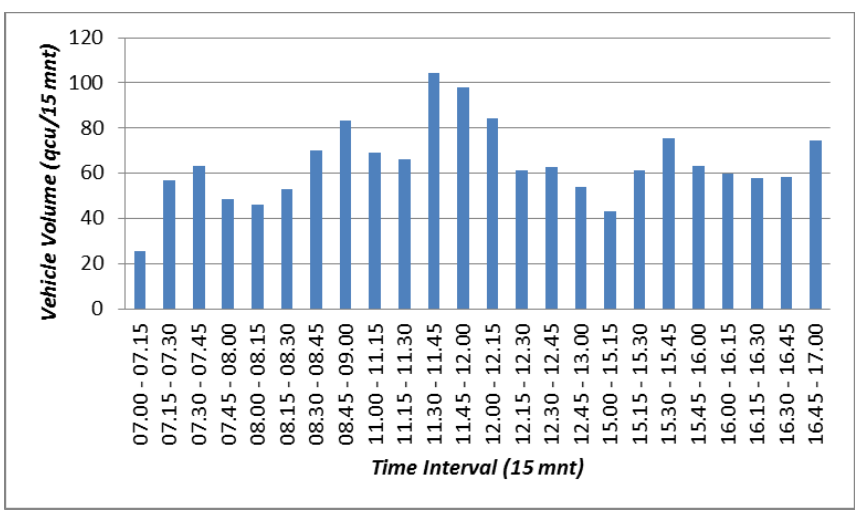

Fig. 4. Volume Data on the Busiest Day for Jl. Pendidikan

Based on the traffic volume data in "Figure 4", the average daily traffic can be calculated, which is by 3525 passenger car unit/day.

The road length and width of Jl. Pendidikan, Jl. Kamizaun, and Jl. Ternate are equal to $1,150 \mathrm{~m} \times 3.5 \mathrm{~m} ; 750 \mathrm{~m} \times 7 \mathrm{~m}$; and $1,700 \mathrm{~m} \times 5 \mathrm{~m}$, respectively.

\section{B. Pavement Damage}

Pavement damage conditions are important to determine countermeasures the authorities need to take.

\section{1) Scores for Pavement Damage Conditions}

Based on the score for the average daily traffic, traffic classes were determined based on data on the Average Daily Traffic as shown in Table 2 [8][6].

TABLE II. TRAFFIC Classes

\begin{tabular}{|c|c|}
\hline Traffic Class & Average Daily Traffic \\
\hline 0 & $<20$ \\
\hline 1 & $20-50$ \\
\hline 2 & $50-200$ \\
\hline 3 & $200-500$ \\
\hline 4 & $500-2,000$ \\
\hline 5 & $2,000-5,000$ \\
\hline 6 & $5,000-20,000$ \\
\hline 7 & $20,000-50,000$ \\
\hline 8 & $>50,000$ \\
\hline
\end{tabular}

Pavement damage assessment based on the damage score of each type of damage is shown in Table 3[6,7].

table III. PaVement Damage Values

\begin{tabular}{|c|c|}
\hline \multicolumn{2}{|c|}{ Pavement Condition Assessment } \\
\hline Score & Value \\
\hline $26-29$ & 9 \\
\hline $22-25$ & 8 \\
\hline $19-21$ & 7 \\
\hline $16-18$ & 6 \\
\hline $13-15$ & 5 \\
\hline $10-12$ & 4 \\
\hline $7-9$ & 3 \\
\hline $4-6$ & 2 \\
\hline $0-3$ & 1 \\
\hline \multicolumn{2}{|c|}{ Cracking } \\
\hline Type & Score \\
\hline Alligator & 5 \\
\hline Random & 4 \\
\hline Transversal & 3 \\
\hline Longitudinal & 2 \\
\hline None & 1 \\
\hline Width & Score \\
\hline$>2 \mathrm{~mm}$ & 3 \\
\hline $1-2 \mathrm{~mm}$ & 2 \\
\hline$<1 \mathrm{~mm}$ & 1 \\
\hline None & 0 \\
\hline \multicolumn{2}{|c|}{ Total Quantity of Damage } \\
\hline Area & Score \\
\hline$>30 \%$ & 3 \\
\hline $10 \%-30 \%$ & 2 \\
\hline$<10 \%$ & 1 \\
\hline 0 & 0 \\
\hline \multicolumn{2}{|c|}{ Rutting } \\
\hline Depth & Score \\
\hline$>20 \mathrm{~mm}$ & 7 \\
\hline $11-20 \mathrm{~mm}$ & 5 \\
\hline $6-10 \mathrm{~mm}$ & 3 \\
\hline $0-5 \mathrm{~mm}$ & 1 \\
\hline None & 0 \\
\hline \multicolumn{2}{|c|}{ Patching and Pothole } \\
\hline Area & Score \\
\hline$>30 \%$ & 3 \\
\hline $20 \%-30 \%$ & 2 \\
\hline $10 \%-20 \%$ & 1 \\
\hline$<10 \%$ & 0 \\
\hline \multicolumn{2}{|l|}{ Surface Roughness } \\
\hline Disintegration & 4 \\
\hline Raveling & 3 \\
\hline Rough & 2 \\
\hline Fatty & 1 \\
\hline Close Texture & 0 \\
\hline Depression & Score \\
\hline$>5 / 100 \mathrm{~m}$ & 4 \\
\hline $2-5 / 100 m$ & 2 \\
\hline $0-2 / 100 \mathrm{~m}$ & 1 \\
\hline None & 0 \\
\hline
\end{tabular}

2) Pavement Damage Data

Types of damage and dimensions for such damage based on measurement results are shown in Tables 4 to 6 . 
TABLE IV. TYPE OF PAVEMENTDAMAgE IN JL.PENDIDIKAN

\begin{tabular}{|c|c|c|c|c|c|}
\hline \multirow{2}{*}{ No } & \multirow{2}{*}{$\begin{array}{c}\text { Type of } \\
\text { Damage }\end{array}$} & \multicolumn{4}{|c|}{ Jl. Pendidikan } \\
\cline { 4 - 6 } & Depth & Quantity & Area & Unit \\
\hline 2 & $\begin{array}{c}\text { Edge } \\
\text { Cracking }\end{array}$ & & & 49.87 & $\mathrm{~m}^{2}$ \\
\hline 2 & $\begin{array}{c}\text { Longitudinal } \\
\text { Cracking }\end{array}$ & & & 0.11 & $\mathrm{~m}^{2}$ \\
\hline 3 & $\begin{array}{c}\text { Transversal } \\
\text { Cracking }\end{array}$ & & & 0.03 & $\mathrm{~m}^{2}$ \\
\hline 4 & $\begin{array}{c}\text { Alligator } \\
\text { Cracking }\end{array}$ & & & 1 & $\mathrm{~m}^{2}$ \\
\hline 5 & $\begin{array}{c}\text { Block } \\
\text { Cracking }\end{array}$ & & & 1.8 & $\mathrm{~m}^{2}$ \\
\hline 6 & Pothole & & & 33.57 & $\mathrm{~m}^{2}$ \\
\hline 7 & Patching & & & 19.31 & $\mathrm{~m}^{2}$ \\
\hline 8 & Rutting & 5 & & & $\mathrm{~mm}$ \\
\hline 9 & Depression & & 2 & & \\
\hline
\end{tabular}

TABLE V. TyPe of PaVement Damage in JL.Kamizaun

\begin{tabular}{|c|c|c|c|c|c|}
\hline \multirow{2}{*}{ No } & \multirow{2}{*}{$\begin{array}{c}\text { Type of } \\
\text { Damage }\end{array}$} & \multicolumn{4}{|c|}{ Jl. Kamizaun } \\
\cline { 5 - 6 } & Depth & Quantity & Area & Unit \\
\hline 1 & $\begin{array}{c}\text { Edge } \\
\text { Cracking }\end{array}$ & & & & $\mathrm{m}^{2}$ \\
\hline 2 & $\begin{array}{c}\text { Longitudinal } \\
\text { Cracking }\end{array}$ & & & 10.89 & $\mathrm{~m}^{2}$ \\
\hline 3 & $\begin{array}{c}\text { Transversal } \\
\text { Cracking }\end{array}$ & & & 0.41 & $\mathrm{~m}^{2}$ \\
\hline 4 & $\begin{array}{c}\text { Alligator } \\
\text { Cracking }\end{array}$ & & & 4.54 & $\mathrm{~m}^{2}$ \\
\hline 5 & $\begin{array}{c}\text { Block } \\
\text { Cracking }\end{array}$ & & & 163.77 & $\mathrm{~m}^{2}$ \\
\hline 6 & Pothole & & & 160.14 & $\mathrm{~m}^{2}$ \\
\hline 7 & Rutting & 10 & & & $\mathrm{Mm}^{2}$ \\
\hline 8 & Depression & & 3 & & \\
\hline
\end{tabular}

TABLE VI. TyPE OF PAVEMENT DAMAgE In JL. TERnATE

\begin{tabular}{|c|l|l|c|c|c|}
\hline No & \multirow{2}{*}{$\begin{array}{c}\text { Type of } \\
\text { Damage }\end{array}$} & \multicolumn{4}{|c|}{ Jl. Ternate } \\
\cline { 5 - 6 } & Depth & Quantity & Area & Unit \\
\hline 1 & $\begin{array}{l}\text { Edge } \\
\text { Cracking }\end{array}$ & & & & $\mathrm{m}^{2}$ \\
\hline 2 & $\begin{array}{l}\text { Longitudinal } \\
\text { Cracking }\end{array}$ & & & 0.79 & $\mathrm{~m}^{2}$ \\
\hline 3 & $\begin{array}{l}\text { Transversal } \\
\text { Cracking }\end{array}$ & & & 0.29 & $\mathrm{~m}^{2}$ \\
\hline 4 & $\begin{array}{l}\text { Alligator } \\
\text { Cracking }\end{array}$ & & & 27 & $\mathrm{~m}^{2}$ \\
\hline 5 & $\begin{array}{l}\text { Block } \\
\text { Cracking }\end{array}$ & & & 8.79 & $\mathrm{~m}^{2}$ \\
\hline 6 & Pothole & & & 205.50 & $\mathrm{~m}^{2}$ \\
\hline 7 & Patching & & & 57.46 & $\mathrm{~m}^{2}$ \\
\hline 8 & Rutting & 5 & & & $\mathrm{~mm}$ \\
\hline 9 & Depression & & 2 & & \\
\hline
\end{tabular}

Scores for the pavement condition index were determined by calculating the mean for all damage scores and scores for each type of damage. Results of the damage score analysis for each road are shown in Tables 7 to 10. The scores for the pavement condition index based on damage scores are shown in Table 7.
TABLE VII. TyPE OF PAVEMENT DAMAgE IN JL.PENDIDIKAN

\begin{tabular}{|c|c|c|c|c|c|c|}
\hline $\begin{array}{l}\text { Type of } \\
\text { Damage }\end{array}$ & $\begin{array}{c}\text { Score } \\
\text { for } \\
\text { Type }\end{array}$ & $\begin{array}{c}\text { Score } \\
\text { for } \\
\text { Width }\end{array}$ & $\begin{array}{c}\text { Score } \\
\text { for } \\
\text { Area }\end{array}$ & $\begin{array}{c}\text { Score } \\
\text { for } \\
\text { Depth }\end{array}$ & $\begin{array}{c}\text { Score for } \\
\text { Depression } \\
\text { Length }\end{array}$ & $\begin{array}{c}\text { Score } \\
\text { for } \\
\text { Damage }\end{array}$ \\
\hline $\begin{array}{c}\text { Polished } \\
\text { Aggregate }\end{array}$ & & & & & & 0 \\
\hline Shoving & - & - & 0 & - & - & 0 \\
\hline Raveling & 3 & - & - & - & - & 3 \\
\hline $\begin{array}{c}\text { Edge } \\
\text { Cracking }\end{array}$ & 1 & 2 & 1 & - & - & 2 \\
\hline $\begin{array}{l}\text { Longitudinal } \\
\text { Cracking }\end{array}$ & 1 & 3 & 1 & - & - & 3 \\
\hline $\begin{array}{c}\text { Transversal } \\
\text { Cracking }\end{array}$ & 3 & 3 & 0 & - & - & 3 \\
\hline $\begin{array}{l}\text { Alligator } \\
\text { Cracking }\end{array}$ & 5 & 1 & 1 & - & - & 5 \\
\hline $\begin{array}{c}\text { Block } \\
\text { Cracking }\end{array}$ & 5 & 1 & 1 & - & - & 5 \\
\hline Pothole & - & - & 0 & - & - & 0 \\
\hline Patching & - & - & 0 & - & - & 0 \\
\hline Rutting & & & & & 1 & 1 \\
\hline Depression & & & & & 1 & 1 \\
\hline \multicolumn{6}{|c|}{ Total } & 23 \\
\hline
\end{tabular}

TABLE VIII. TyPe of PaVement Damage IN JL. Kamizaun

\begin{tabular}{|c|c|c|c|c|c|c|}
\hline $\begin{array}{c}\text { Type of } \\
\text { Damage }\end{array}$ & $\begin{array}{c}\text { Score } \\
\text { for } \\
\text { Type }\end{array}$ & $\begin{array}{c}\text { Score } \\
\text { for } \\
\text { Width }\end{array}$ & $\begin{array}{c}\text { Score } \\
\text { for } \\
\text { Area }\end{array}$ & $\begin{array}{c}\text { Score } \\
\text { for } \\
\text { Depth }\end{array}$ & $\begin{array}{c}\text { Score for } \\
\text { Depression } \\
\text { Length }\end{array}$ & $\begin{array}{c}\text { Score } \\
\text { for } \\
\text { Damage }\end{array}$ \\
\hline $\begin{array}{c}\text { Polished } \\
\text { Aggregate }\end{array}$ & - & - & - & - & - & 0 \\
\hline Shoving & - & - & 0 & - & - & 0 \\
\hline Raveling & 3 & - & - & - & - & 3 \\
\hline $\begin{array}{c}\text { Edge } \\
\text { Cracking }\end{array}$ & & & & - & - & 0 \\
\hline $\begin{array}{c}\text { Longitudinal } \\
\text { Cracking }\end{array}$ & 1 & 3 & 1 & - & - & 3 \\
\hline $\begin{array}{c}\text { Transversal } \\
\text { Cracking }\end{array}$ & 3 & 3 & 1 & - & - & 3 \\
\hline $\begin{array}{c}\text { Alligator } \\
\text { Cracking }\end{array}$ & 5 & 3 & 1 & - & - & 5 \\
\hline $\begin{array}{c}\text { Block } \\
\text { Cracking }\end{array}$ & 5 & 3 & 1 & - & - & 5 \\
\hline Pothole & - & - & 0 & - & - & 0 \\
\hline Patching & - & - & - & - & - & 0 \\
\hline Rutting & - & - & - & 3 & - & 3 \\
\hline Depression & - & - & - & - & 2 & 2 \\
\hline \multicolumn{2}{|c|}{ Total } & & & 24 \\
\hline
\end{tabular}


TABLE IX. TYPE OF PAVEMENT DAMAGE IN JL. TERNATE

\begin{tabular}{|c|c|c|c|c|c|c|}
\hline $\begin{array}{c}\text { Type of } \\
\text { Damage }\end{array}$ & $\begin{array}{c}\text { Score } \\
\text { for } \\
\text { Type }\end{array}$ & $\begin{array}{c}\text { Score } \\
\text { for } \\
\text { Width }\end{array}$ & $\begin{array}{c}\text { Score } \\
\text { For } \\
\text { Area }\end{array}$ & $\begin{array}{c}\text { Score } \\
\text { for } \\
\text { Depth }\end{array}$ & $\begin{array}{c}\text { Score for } \\
\text { Depression } \\
\text { Length }\end{array}$ & $\begin{array}{c}\text { Score } \\
\text { for } \\
\text { Damage }\end{array}$ \\
\hline $\begin{array}{c}\text { Polished } \\
\text { Aggregate }\end{array}$ & 4 & - & - & - & - & 3 \\
\hline Shoving & - & - & - & - & - & 0 \\
\hline Raveling & - & - & - & - & - & 0 \\
\hline $\begin{array}{c}\text { Edge } \\
\text { Cracking }\end{array}$ & - & - & - & - & - & 0 \\
\hline $\begin{array}{c}\text { Longitudinal } \\
\text { Cracking }\end{array}$ & 1 & 3 & 1 & - & - & 3 \\
\hline $\begin{array}{c}\text { Transversal } \\
\text { Cracking }\end{array}$ & 3 & 3 & 1 & - & - & 3 \\
\hline $\begin{array}{c}\text { Alligator } \\
\text { Cracking }\end{array}$ & 5 & 3 & 1 & - & - & 5 \\
\hline $\begin{array}{c}\text { Block } \\
\text { Cracking }\end{array}$ & 5 & 3 & 1 & - & - & 5 \\
\hline Pothole & - & - & 0 & - & - & 0 \\
\hline Patching & - & - & 0 & - & - & 0 \\
\hline Rutting & - & - & - & 1 & - & 1 \\
\hline Depression & - & - & - & - & 1 & 1 \\
\hline
\end{tabular}

TABLE X. SCORES FOR THE PAVEMENT CONDITION INDEX

\begin{tabular}{|c|c|c|}
\hline Road Name & $\begin{array}{c}\text { Score for } \\
\text { Damage }\end{array}$ & $\begin{array}{c}\text { Score for the } \\
\text { Pavement Condition Index }\end{array}$ \\
\hline Jl. Pendidikan & 23 & 8 \\
\hline Jl. Kamizaun & 24 & 8 \\
\hline Jl . Ternate & 21 & 7 \\
\hline
\end{tabular}

Based on the scores for the road condition index and traffic classes, it is revealed that the priority scores for Jl. Pendidikan, J1. Kamizaun, and J1. Ternate are 43 , and 5, respectively. Based on those results, it is necessary to include Jl. Pendidikan and $\mathrm{Jl}$. Ternate in the periodic maintenance program while $\mathrm{Jl}$. Kamizaun needs to be included in the improvement program.

Based on the whole data analysis undertaken, a model for the relationship between the traffic volume and the score for the pavement condition index was then examined. The analysis of the relationship model was undertaken using the application Microsoft Excel. The variables used in the analysis were the score for the pavement condition index as the dependent variable (y) and the traffic volume as the independent variable (x). Results of the analysis undertaken using regression generated a multiple $\mathrm{R}$ value of 0.4124 , which means that the traffic volume does not exercise a significant effect on the score for the pavement condition index, the $\mathrm{R}$ square by 0.1701 means that the model's goodness of fit is not really good. The resulting model equation is $y=6.53597+0.00027 x$. Results of the pavement condition assessment using the equaltion above are shown in Table 11.
TABLE XI. SCORES FOR THE ROAD CONDITION INDEX BASED ON THE MODEL EQUATION

\begin{tabular}{|c|c|c|}
\hline Road Name & $\begin{array}{c}\text { Traffic } \\
\text { Volume }\end{array}$ & $\begin{array}{c}\text { Score for } \\
\text { Pavement } \\
\text { Condition }\end{array}$ \\
\hline Jl. Pendidikan & 3525 & 7.5 \\
\hline Jl. Kamizaun & 5101 & 7.9 \\
\hline Jl.Ternate & 3695 & 7.5 \\
\hline
\end{tabular}

\section{CONCLUSIONS}

Based on field measurement results, it is revealed that the volume of traffic in Jl. Pendidikan, Jl. Kamizaun, and Jl. Ternate reaches $3525 \mathrm{pcu} /$ day; $5101 \mathrm{pcu} / \mathrm{day}$; and $3695 \mathrm{pcu} /$ day, respectively. The road length and width of Jl. Pendidikan, Jl. Kamizaun, and Jl. Ternate are equal to $1150 \mathrm{~m}$ x $3.5 \mathrm{~m}$; $750 \mathrm{~m} \times 7 \mathrm{~m}$; and $1700 \mathrm{~m} \times 5 \mathrm{~m}$, respectively. The types of damage identified include polished aggregate, shoving, raveling, edge cracking, longitudinal cracking, transversal cracking, crocodile cracking, block cracking, pothole, patching, rutting, and depression. Scores for the Pavement Condition Index are 8 for Jl. Pendidikan, 8 for Jl. Kamizaun, and 7 for Jl. Ternate. The model equation generated based on analysis results is $y=6.53597+0.00027 x$ with the value of $R$ squared by 0.1701 . Scores for the Pavement Condition Index generated based on the model equation are 7.5 for $\mathrm{Jl}$. Pendidikan, 7.9 for Jl. Kamizaun, and 7.5 for Jl. Ternate.

\section{ACKNOWLEDGMENT}

We thank Universitas Musamus for facilities, supports, and publications.

\section{REFERENCES}

[1] P.J.U.I. Made, S.Andre, "Analisa faktor penyebab kerusakan jalan (studi kasus ruas jalan W. J. Lalamentik dan ruas jalan Gor Flobamora)," J. Tek. Sipil, vol. II, pp. 13-18, 2014.

[2] BPS Kabupaten Merauke, Merauke Dalam Angka. BPS Kabupaten Merauke, 2017.

[3] H.F. Betaubun and P. Betaubun, "Evaluation Of The Performance Of Traffic Signs For Vehicle Speed Limits,” Int. J. Civ. Eng. Technol., vol. 9, pp. 568-573, 2018.

[4] Najid and H.F. Betaubun, "Pengaruh Karakteristik Jalan dan Tata Guna Lahan pada Penentuan Kapasitas Jalan Studi Kasus: Jakarta Barat," FSTPT, p. 11, 2012.

[5] O. Tamin, Perencanaan dan Pemodelan Tranportasi, Bandung: Penerbit ITB, 1997.

[6] D.P.J.K. Direktorat Jenderal Bina Marga, Tata Cara Penyusunan Program Pemeliharaan Jalan Kota, no. 18. 1990.

[7] I. Wirnanda, R. Anggraini, and M. Isya, "Analisis tingkat kerusakan jalan dan pengaruhnya terhadap kecepatan kendaraan (studi kasus jalan Blang Bintang Lama dan jalan Teungku hasan Dibakoi)," Tek. Sipil Univ. Syah Kuala, vol. 1, pp. 617-626, 2018.

[8] W.G.C. Deby, "Perbandingan metode Bina Marga dan metode PCI (Pavement Condition Index) dalam penilaian kondisi perkerasan jalan (studi kasus simpang Lago-simpang batam," JomFTEKNIK, vol. 5, pp. 1-11, 2018.

[9] A.C.M. Hustim, M. Asad, "Analisis nilai kondisi lapis perkerasan jalan pada ruas jalan arteri primer di Kota Makassar," [in the 18th FSTPT Inter. Symp., Unila, Bandar Lampung, August 28, 2015]. 